\title{
Activity-Based Costing for Pathology Examinations and Comparison with the Current Pricing System in Turkey
}

\section{Patoloji Tetkiklerinde Faaliyet Tabanlı Maliyet Hesaplaması ve Güncel Fiyatlandırma Sistemi İle Karşılaştırılması}

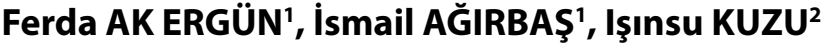 \\ 'Department of Health Services Management, Ankara University, Faculty of Health Sciences, ANKARA, TURKEY, \\ ${ }^{2}$ Department of Pathology, Ankara University, Faculty of Medicine, ANKARA, TURKEY
}

\begin{abstract}
Objective: To demonstrate the real cost data of the pathology examinations by using the activity-based costing method and to contribute to the financial planning of the departments, health managers and also the social security institution.
\end{abstract}

Material and Method: Forty-four examinations selected from the Healthcare Implementation Notification system list and performed at the Ankara University Faculty of Medicine Pathology Department during September 2010 were studied. The analysis and the real cost calculations were done according to the duration of the procedures. Calculated costs were compared with the Healthcare Implementation Notification system and Medicare price lists.

Results: The costs of the pathology tests listed within the same pricing levels in the Healthcare Implementation Notification system list showed great differences. The minimum and maximum costs in level $1,2,3$, and 4 were 15,98-80,15 TL, 15,95-258,59 TL, 42,38- 236,87 TL, and 124,42-406,76 TL, respectively. Medicare price levels were more consistent with the real costs of the examinations compared to the Healthcare Implementation Notification system price list.

Conclusion: The prices of the pathology examination listed at different levels in the Healthcare Implementation Notification system lists do not cover the real costs of the work done. The principal parameters of Activity-Based Costing system are more suitable for making the most realistic cost categorization. Although the prices could differ between countries, the Medicare system categories are more realistic than the Healthcare Implementation Notification system. The Healthcare Implementation Notification system list needs to be revised in order to reflect the real costs of the pathology examinations.

Key Words: Pathology, Cost analysis, Financial activities, Turkey
(Turk Patoloji Derg 2013, 29:1-14)

Received : 30.07.2012 Accepted : 06.09.2012
ÖZ

Amaç: Faaliyet Tabanlı Maliyet sistemi kullanılarak patoloji tetkiklerinde doğru maliyet verilerini ortaya koymak, sağlık yöneticilerine, geri ödeme kurumuna finansal planlama, kalite geliştirmede katkı sağlamak ve maliyetlerin kontrol edilebilmesi için araç sunmak.

Gereç ve Yöntem: Ankara Üniversitesi Tip Fakültesi Tibbi Patoloji Anabilim Dalı Patoloji laboratuvarında 2010 yılı ekim ayında yapılan histopatolojik incelemeler içinden Sağlık Uygulama Tebliği'nde belirlenmiș dört düzeyde farklılıklar bulunduran, model olabilecek 44 inceleme seçilmiştir. Bunların laboratuvar basamakları üzerinden süreleri esas alınarak gerçek maliyetleri hesaplanmıştır. Maliyetler Sağlık Uygulama Tebliği ve Medicare fiyatlandırma sistemleri ile karşılaştırılmıştır.

Bulgular: Histopatolojik tetkiklerin Sağlık Uygulama Tebliği listesinde aynı düzeyde olanların çoğunda birim maliyetleri birbirinden farklıdır. 1. düzeyde en düşük 15,98 TL maliyetle kolesistektomi, en yüksek 80,15 TL maliyetle ile prostat iğne biyopsisi bulunmuştur. 2 . düzeyde en düşük 15,95 TL maliyetle apendektomi, en yüksek 258,59 TL maliyetle ampütasyon bulunmuştur. 3. düzeyde en düşük 42,38 TL maliyetle TUR, en yüksek 236,87 TL maliyetle basit mastektomi bulunmuştur. 4. düzey içinde yer alan en düşük maliyetli inceleme 124,42 TL ile dil/tonsil tümör içeren rezeksiyon, en yüksek 406,76 TL maliyetle larinks, parsiyel/total ve boyun lenf nodları olduğu bulunmuştur.

Sonuç: Sağlık Uygulama Tebliği'nde düzeylere göre belirlenen patoloji tetkik fiyatları bu incelemelerin gerçek maliyetlerini yansıtmamaktadır. Faaliyete dayalı maliyet sistemi ile hesaplanan maliyetler sağlık kurumunun hizmet türü ve hizmet basamağına göre değişiklikler gösterebilir. Ancak yöntemin temel parametreleri patoloji tetkiklerinin daha doğru düzeylendirilmesi gerektiğini göstermiştir. Medicare sisteminin benzer amaçlı ülkemizde uygulanan Sağlık Uygulama Tebliği sisteminden çok daha gerçekçi ve fiili maliyeti yansıtan bir ücretlendirme sistemi olduğu anlaşılmaktadır. Fiyatlar ülkelere göre farklılık gösterse de Sağlık Uygulama Tebliği listesindeki tetkiklerin düzeylerinin maliyeti yansıtacak şekilde yeniden gözden geçirilmesi gerekmektedir.

Anahtar Sözcükler: Patoloji, Masraf analizi, Finansal aktiviteler, Türkiye

Correspondence: Işınsu KUZU

Department of Pathology, Ankara University, Faculty of Medicine,

ANKARA, TURKEY

E-mail: isinsukuzu@yahoo.com Phone: +90 5336365717 


\section{INTRODUCTION}

The countries which have well organized health services on a certain level generally have well organized economic, political and social structures. The amount of money spent for health and healthcare which have important role on the individuals and societies life are gradually increasing. An important part of the domestic income of the countries and also the incomes of the individuals are spent for healthcare costs. As a result of this situation, healthcare costs always keep its importance and consistent position on the agenda. The policies conducted by the public and private sector directly affect healthcare services. Within the scope of these policies, the decisions regarding healthcare services should be based on scientific evidence (1). None of the countries have adequate resources to cover all the healthcare needs of its population (2). The healthcare services should have international standards on diagnosis, treatment and patients care and expected to be fast with high quality, but low in price, responding the needs and expectations of the patients. The hospitals which constitute the subsystem of healthcare, are prone to maintain getting highest benefit with the allocated short resources. Therefore the hospitals should keep their costs under control, calculate their expenses regularly and determine the unit costs for the main production areas (3).

In the most general sense, the concept of cost can be stated as the total of the sacrifices tolerated to reach a certain aim and is generally measured with money. Based on this definition, the concept of cost in hospitals can be defined as the financial statement of the sacrifices tolerated to submit a certain healthcare standard regarding diagnosis, treatment and prevention by focusing mostly on the healthcare service (4). The cost of a produced service consists of three basic components. These are expenses of the;

- Direct raw materials and supplies,

- Direct labor costs, and

- General production costs.

The direct raw material and supplies are the basic elements of the service and can be traced directly (5). These expenses consist of the costs of the drugs and medical material used in producing service by the hospitals. The direct labor costs are the expenses for workmanship occur during the service production and can directly be added to the service cost. In terms of healthcare, the wages of the healthcare staff working at the hospital are the direct labor costs (6). The general production costs are defined as all costs related to production except, direct raw material and direct labor costs (7). The expenses of electricity, water, natural gas, communication, cleaning, food and suchlike things used up at the hospitals are composing the general production costs. Activity Based Costing (ABC) aims to determine all activities of the health institutions during the healthcare production period, to provide information about the consumed resources of these activities and to submit this information to the managers for helping them on making their strategic decisions (8). Because it assigns the costs in an activity-oriented manner instead of considering the department's production volume or number, $\mathrm{ABC}$ provides a more accurate costing. (9). This system helps the managers to analyze the general production expenses in detail. It also determines the units working inefficiently or wasting resources, and ensures reducing the costs by decreasing the unnecessary expenses. The $\mathrm{ABC}$ system is a tool to reduce the cost of the facilities and wasting (10). $\mathrm{ABC}$ measurement and performance measurement are the two basic elements of this system. $A B C$ is a method used to measure the performance and costs of the objects, resources and activities. Activities using resources to produce output constitute the basic concept of $\mathrm{ABC}$ (11). There are two main levels in the ABC system. In the first level, the institution resources being consumed by the activities encountered during the production period of the institution are defined. In the second level, the relationship between costs of the activities, the products or produced services are established. For doing this, first, the production activities carried out during the production process of the healthcare institution are defined and similar activities are then gathered in activity pools and the costs of the activity pools are determined. Later, the costs collected in activity pools are associated with products or services (12). In order to make the application stage of $\mathrm{ABC}$ system easier for the managers, the two main levels composing the method are increased to six special steps. These are; determination of the activities, determination of the activity centers, detection of the cost factors, calculation of activity costs, transferring the costs to the activity centers, and loading the costs to the products or to the services (8).

The application of the ABC system to the hospitals in Turkey is not common. The reasons are; inadequate establishment of accounting information systems of the hospitals, lack of awareness of cost and management accounting, lack of enthusiasm about searching the true costs due to the state dependence of the hospital pricing, requirement of wellinformed staff for $\mathrm{ABC}$ application, the difficulty and high prices of determining activities and the costing indicators (6). The ABC system is a costing system that distributes the 
costs only according to the relevant service and/or service groups. With this feature, it has the advantage of obtaining more accurate costs in healthcare institutions by loading the general production costs to the services correctly (13).

Pathology laboratory services have an operation that requires different material, different associated processing steps and different laboratory personnel at every step compared to laboratories of biochemistry, microbiology, hematology, and genetics. The nature and steps of pathology investigations are not prepared completely by automated devices as in other laboratories. They include procedures that partly achieved by automated instruments and still requiring human labor. The calculation of the real costs of the pathology laboratory tests is possible by determining the activities of the service steps. In this study, we tried to demonstrate that more accurate costing figures can be obtained by using the $\mathrm{ABC}$ system. In this study, we aimed to calculate the actual costs of pathological examinations completed at the Ankara University Faculty of Medicine Department of Pathology by performing the $\mathrm{ABC}$ analysis. Our objective was to provide a tool for the healthcare managers at the institution for financial planning, performance monitoring, quality improvement efforts and cost control. Additionally, we aimed to investigate the compatibility of prices of the pathology examinations that are determined in the Healthcare Implementation Notification (HIN)(SUT) system by the Republic of Turkey Social Security Institution (SSI)(SGK) with the Medicare (14) pricing level applied in the Unites States of America (USA).

\section{MATERIAL and METHODS}

Histopathological examinations that can be a model for all pathology investigations were selected as the sample. During the selection, one representative test was chosen among the tests which are present in each level of the HIN list, having similarities on consumables, preparation and evaluation stages. All of the tests which do not show similarities in terms of labor and consumables but present in the same level within the HIN list were studied. In order to determine the amount of samples, the number of tests performed within 2010 October and the expenses for these tests in this time period are considered.

In the data collection stage, the medical, administrative, financial and technical records of the hospital were utilized; activities and resources consumed by the activities were identified by interviews with the employees. In determining the activities, the work flow diagram composed by the help of the employees of the pathology laboratory were used.
Data regarding activities and the direct laboring durations of each activity were collected by observation. In cases where data were not available, information obtained from faculty members, specialists and/or assistants, laboratory assistant, secretary, staff, patient records, and archivist were recognized as "expert opinion". Cost analysis studies were performed on a quarterly basis in the hospital where the study was conducted. Data related to direct raw materials and other supplies, direct labor and general production costs were obtained from the data prepared by the cost analysis unit. All payments made to the staff both from the special and the revolving budgets were calculated in gross by including all expense items for the cost analysis studies. Depreciation of buildings, which is within the scope of general production expenses were calculated for 100 years and instruments depreciation were calculated for 5 years. Revaluation ratios published legally were used in the calculations.

As the research was performed with 2010 data, the calculated unit cost figures were compared with the HIN 2010 figures. Changes were made in the HCT in 2011 and 2012 but no changes were made in the Pathology test prices. To serve as a source for future studies and to perform a comparison with foreign applications, unit costs were transformed to the currencies Euro $(€)$ and U.S. Dollars (\$) in this period of time.

While calculating the costs of direct raw material and supplies, first the cost of material used to prepare a paraffin block was multiplied with the number of blocks used for the materials and the material block cost was found; the cost of the material used to stain a slide was then multiplied with the number of slides used for the material and the material slide cost was found. Total direct raw material and supplies cost of each material was calculated by adding the block cost and the slide cost. As there is no need to prepare paraffin block for the aspirations and imprint investigations, no paraffin blocking cost calculation performed. Materials such as special stainings and special fixation or decalcification solutions (Hollande, formic acid, formaldehyde) were used for some materials. The costs of these additional materials were subsequently added to the cost. After the paraffin blocks are prepared, paraffin sections are obtained, the sections are stained and coverslipped. These procedures consist of the same stages for one slide in all materials. The number of slides changes according to the material type and special stains are used besides routine staining for some materials. The materials used for slide staining and their unit prices were used and the staining cost of a slide was found. The number of slides 
for the materials and the cost of staining of one slide was multiplied in order to get the cost of the procedures used for material staining. For materials, the paraffin block preparation cost and costs which occur due to the number of paraffin blocks and routine staining of paraffin sections were found by multiplying these with the number of slides and by taking the sum of these multiplications to provide the direct raw material and supplies cost. Special staining cost and the costs for special materials where special staining is performed routinely, the cost of mean formaldehyde amount used according to the size of the container for larger resection materials, the mean amount of formic acid which is used for decalcification of the bone tissue, and the cost of eosin used in preliminary fixation step for prostate biopsies were added to the calculations. The direct raw material and supplies cost for each material was calculated.

Following the calculation of direct raw material and supplies costs for all of the materials included in the study, the direct labor costs and durations of involvement for these materials were calculated. Direct labor costs were constituted first by calculating charges of employees' per second. Then, how much time the faculty member, specialist and/or assistant, laboratory staff, registration staff, report secretary, material transfer staff and the archive staff spent for working on each material was found. The time spent for each process by the staff was obtained by using chronometer. Data regarding activities and direct labor duration were collected by observation. The time spent for patient record and sample reception, material identification and macroscopic examination, tissue processing, embedding, cutting, staining, coverslipping, and control process of paraffin sections, and the activity result reporting centers were measured separately. In other activity centers, the time recorded for transfer staff for delivery of the material to the laboratory, faculty members for the microscopic examination, report secretaries for typing the reports, archive attendants for archival storage center were evaluated. The cost of the employee for that material was obtained by multiplying the times found and the employees' charges per seconds. Finally, all employee costs regarding that material were added and the material direct labor cost was obtained.

The direct labor and direct material costs needed to calculate the real cost of a pathological examination is loaded on the material directly and general production costs are loaded by using some distribution factors. In the study, the general production costs are collected under 11 different titles as indirect staff costs, electricity charges, water charges, gas expenses, communication expenses, cleaning expenses, food expenses, inventory, depreciation expense, amortization expense for buildings, stationery and supplies expense and other expenses. While investigating the materials in this study, the realized activities were determined. These activities were evaluated with pthologists and the similar ones were collected under an activity center to form activity centers. These activity centers formed were patient record and sample acceptance delivery of the material to the laboratory, material identification and macroscopic examination, tissue processing, paraffin embedding, cutting, staining, coverslipping and controlling the process of paraffin profiles, microscopic examination, report typing, results reporting, and archiving.

The general production expenses obtained from the Cost Analysis studies were distributed to the activity centers by using the 1st stage distribution factors. The first stage cost distribution factors were determined as working hours, area, and device operating times. Working hours were obtained by interviewing the pathologists. In the study, some general production expenses such as electricity, natural gas, water were distributed to activity centers by using the areas covered by the activity centers. Working hours were used when distributing the indirect staff expenses. In areas with a distribution factor, the whole area of the Pathology Department and areas of rooms where the activities are realized in the activity centers were used. Fixed asset depreciation distribution was performed by using the unit costs of some important devices in the activity centers.

When the direct labor time and charges were calculated using the monthly, hourly and secondly wages of the staff working in the pathology laboratory, the mean total October wages of all professors was taken. Since there is 20 working days in October, the daily professor fee was obtained by dividing this mean value into 20 . The hourly fee was calculated by dividing the wage found into 8 by assuming that they worked 8 hours a day. Because of the difference of the working hours of the staff due to shifts, they were assumed to work 8 hours daily. Then, minute and second wages were calculated from the obtained number.

In the hospital where the study was conducted, the frozen investigations are done at two different laboratories, one in Cebeci Hospital center surgical building and at the side of the İbni Sina Hospital operating room. Other materials except the frozen investigation in the study are investigated in the Pathology laboratory which is located in the morphology building. Cost Analysis studies were separately conducted in the Morphology Building, Cebeci Hospital and İbni Sina Hospital. The frozen investigation has a different workflow than the other materials. The frozen investigation analysis 
was therefore performed separately from other materials and has been shown separately on the tables.

The general production expenses obtained from the Cost Analysis studies were distributed to the activity centers by using the 1st stage distribution factors. In the second distribution, expenses belonging to the auxiliary service cost places and general administration cost places are present. The data here are obtained from the Cost Analysis Unit. Here, the share obtained from the 2nd distribution was reflected to the sum of the 1st distribution. In the third stage cost distribution, the costs loaded to the activity centers were loaded to the materials. The material factor which is used in loading the costs accumulated at the activity centers to the materials is selected by taking the structure of the realized activities into account. For all activity centers in the study, the converted procedure time was used as the 3rd stage cost factor. As an example, the unit and total cost calculations for lung transbronchial biopsy were stated in all activity centers. Because the procedure time is the same for all materials regarding patient register and sample acceptance and result reporting activity centers, the total number of materials registered in October was multiplied with the procedure time. In the other activity centers, the procedure time changes according to the materials. For this reason and as the procedure time for the materials which are not in scope of the study is unknown, when the process was being done we took the amount for 1408 materials from the cost amount of 2088 materials (as the frozen calculations were performed separately, 30 frozen materials were not taken here).

The general production expenses were loaded to the activity centers with distribution factors. The general production costs gathered in the activity centers were loaded again by the help of cost factors and the general production cost of each material was determined.

The cost of a material is obtained by gathering the direct raw material and supplies cost, direct labor cost and indirect cost of that material. The differences and prices of the obtained costs of the selected pathology tests were compared within their HIN levels. The investigation fees and levels of Medicare were compared with the prices of the Nebraska state Medicare (http://www.wpsmedicare.com) pricing system that is officially determined in the United States of America but differs in each state.

\section{RESULTS}

In our study, the total material number that came to the laboratory of Ankara University Pathology Department was found to be 2088. In the same period, a total of 1438 histopathological investigations of 44 kinds of specimen taken into the scope of the study were performed.

In the study, the material cost used for preparing a block was found to be $2,79 \mathrm{TL}$.

After the paraffin block was prepared, the staining cost of a slide within the unit costs for the paraffin cutting and routine Hematoxylin-Eosin (H\&E) staining and coverslipping process of the sections afterwards was found to be 0,38 TL. For staining, the special staining material costs applied routinely to the materials included in the study were found as iron staining 0,24 TL, reticulin staining 0,75 TL, May Grunwald Giemsa staining 0,32 TL, Giemsa staining 0,53 TL, Periodic Acid Schiff Methenamine staining 1,81 TL, Periodic Acid Shiff (PAS) staining 0,25 TL, Tricrom staining 5,30 TL, Amyloid staining (Gentian violet) 0,29 TL, Elastic van gieson staining 3,21 TL. In Table I, the calculation of direct raw material and supplies costs are shown with one example from four levels.

As a result of the calculations, the wages per second of the employees were found as follows; Faculty member 0,011 TL (professor and associate professors were accepted as faculty members in this study), Specialist and/or Resident 0,005 TL, Laboratory and Archive Staff 0,004 TL, Report Secretary, Register Staff and Staff Carrying Material 0,003 TL.

In Table II, an example from every level was given for the material direct labor costs obtained by multiplying the labor duration of the materials and the staff's wages per second.

In order to calculate the cost of a material, the direct raw material and general material, direct laboring and general production costs should be calculated.

The loading of the general production expenses to the activity centers is shown on Table III and general production expenses of the sample materials of four levels are given on Table IV.

If we take the lung transbronchial biopsy investigation as an example of calculation, the patient register and sample acceptance procedure for this material is performed by the register staff in 50 seconds. The total procedure time spent for the register and sample acceptance procedure of all materials in October is $2.088 \times 50$ seconds $=104.400$ seconds. This time was divided into the patient register and sample acceptance activity center, and the unit transformed process cost was obtained (4.394,42 TL/104.400 seconds $=0,0420 \mathrm{TL} /$ second). In the calculation made for the lung trans-bronchial biopsy investigation, $0,0420 \mathrm{TL} /$ seconds $\mathrm{x}$ 50 seconds $=2,10 \mathrm{TL}$ unit cost was found. The obtained 
Table I: The costs of direct raw material and supplies used for pathology materials in investigations taken as example

\begin{tabular}{|c|c|c|c|c|c|c|c|c|}
\hline $\begin{array}{l}\text { Material } \\
\text { Type }\end{array}$ & 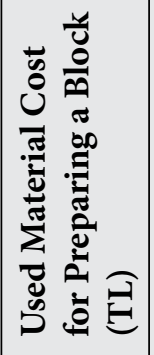 & 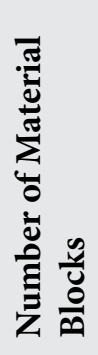 & 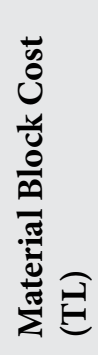 & 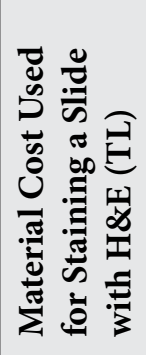 & 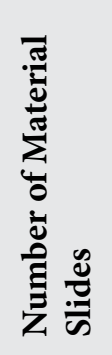 & 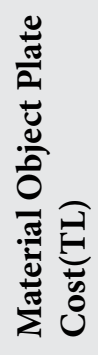 & 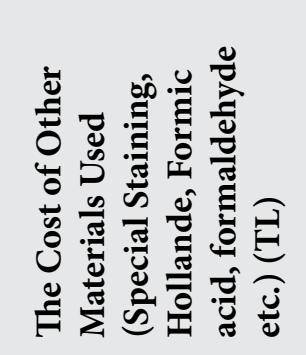 & 可 \\
\hline $\begin{array}{l}\text { Lung trans-bronchial } \\
\text { biopsy }\end{array}$ & 2,79 & 1 & 2,79 & 0,38 & 2 & 0,76 & - & 3,55 \\
\hline Kidney, biopsy needle & 2,79 & 1 & 2,79 & 0,38 & 3 & 1,14 & $\begin{array}{c}\text { Pas: } 0,25 \\
\text { Pasm: } 1,81 \\
\text { Amyloid: } 0,29 \\
\text { Trichrome: } 5,30\end{array}$ & 11,58 \\
\hline $\begin{array}{l}\text { Prostate, needle biopsy } \\
\text { (quadrant } 10 \text { and over) }\end{array}$ & 2,79 & 14 & 39,06 & 0,38 & 42 & 15,96 & Eosin: 1,63 & 56,65 \\
\hline $\begin{array}{l}\text { Lung, total/lobe/segment } \\
\text { resection }\end{array}$ & 2,79 & 14 & 39,06 & 0,38 & 15 & 5,70 & $\begin{array}{c}\text { Formaldehyde: } 0,15 \\
\text { EVG: } 3,21\end{array}$ & 48,12 \\
\hline
\end{tabular}

Table II: Direct labor costs of materials in investigations taken as sample

\begin{tabular}{|c|c|c|c|c|c|c|c|c|}
\hline $\begin{array}{l}\text { Material } \\
\text { Type }\end{array}$ & 章泀引 & 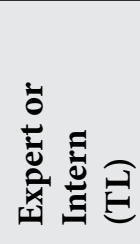 & 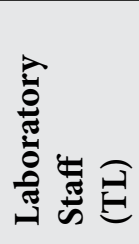 & 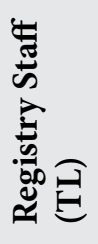 & 紊营 & 总 & 胥 & 흉 \\
\hline $\begin{array}{l}\text { Lung trans-bronchial } \\
\text { biopsy }\end{array}$ & 3,96 & 1,05 & 2,00 & 0,19 & 0,72 & 0,14 & 0,48 & 8,54 \\
\hline Kidney, biopsy needle & 28,08 & 6,53 & 80,72 & 0,19 & 2,34 & 0,14 & 1,48 & 119,48 \\
\hline $\begin{array}{l}\text { Prostate, needle biopsy } \\
\text { (quadrants } 10 \text { and over) }\end{array}$ & 17,02 & 8,42 & 13,41 & 0,19 & 1,80 & 0,14 & 6,20 & 47,18 \\
\hline $\begin{array}{l}\text { Lung, total/lobe/segment } \\
\text { resection }\end{array}$ & 17,65 & 8,04 & 17,49 & 0,19 & 4,41 & 0,14 & 3,60 & 51,52 \\
\hline
\end{tabular}

unit material and total material number was multiplied $(2 \times 2,10 \mathrm{TL}=4,20 \mathrm{TL})$ and the total cost of lung transbronchial biopsy investigation in the patient register and sample acceptance activity center was found. 1408 materials we investigated as the sample make up $67,43 \%$ of the total material number. For this reason, $67,43 \%$ of the amount belonging to the activity center was taken.

The unit costs belonging to the 44 materials within the scope of this study were calculated in this way and are given on Table V.

The Pathology test costs in our study vary in a wide cost range between 15,98 TL at the lowest and 406,76 TL at the highest. Comparison of HIN prices applied by HSI with the investigation costs we found provided the data on Table VI. In order to be able to use the calculated unit costs in future studies and to make comparisons, the Euro and Dollar equivalents were also given in this table. Besides, Medicare payment system prices are also given on this table to compare the price difference between the investigations on the same level on the HIN list.

When the prices determined in four levels on the HIN list created by the HSI and the costs obtained in our study were compared, the biggest part of HIN prices in the first level were found to cover the costs but some did not cover the 


\begin{tabular}{|c|c|c|c|c|c|c|c|c|c|c|c|c|}
\hline 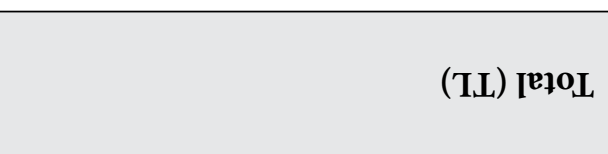 & 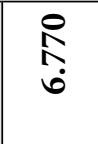 & 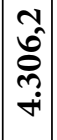 & $\begin{array}{c}\hat{\sigma} \\
\partial \hat{\alpha} \\
\dot{\alpha} \\
\dot{i}\end{array}$ & $\begin{array}{l}+1 \\
\hat{\Omega} \\
\curvearrowright\end{array}$ & $\begin{array}{l}\hat{\text { aे }} \\
\stackrel{\text { a }}{1}\end{array}$ & $\begin{array}{l}0 \\
\hat{N} \\
\tilde{\omega} \\
0 \\
i\end{array}$ & ถิ. & $\begin{array}{c}\sigma \\
10 \\
\\
\\
-\end{array}$ & مָ & $\underset{\sigma}{\tilde{F}}$ & 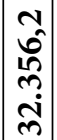 & 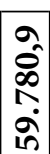 \\
\hline 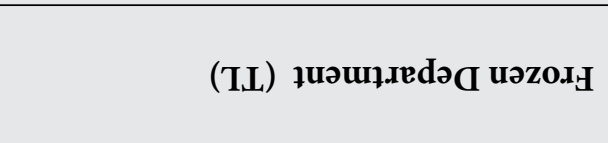 & 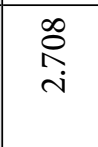 & 1 & 1 & 1 & 1 & ' & 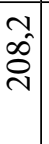 & $\begin{array}{l}n \\
\stackrel{1}{N} \\
\end{array}$ & ' & $\begin{array}{l}20 \\
6 \\
\overrightarrow{7} \\
i \\
i\end{array}$ & 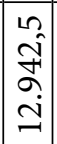 & 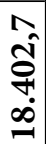 \\
\hline (TL) әк!Чग. & $\begin{array}{l}0 \\
\stackrel{0}{F} \\
\text { in }\end{array}$ & 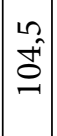 & \begin{tabular}{|c|}
$\infty$ \\
1 \\
$\infty$ \\
$\infty$ \\
$n$
\end{tabular} & $\begin{array}{ll}1 \\
\stackrel{2}{0} \\
-1\end{array}$ & $\hat{\sigma}$ & $\begin{array}{l}a \\
\hat{6} \\
\hat{n}\end{array}$ & $\stackrel{\substack{f \\
F}}{-}$ & $\stackrel{\wedge}{\sim}$ & $\begin{array}{l}n \\
0 \\
\hat{N} \\
\hat{n}\end{array}$ & $\stackrel{m}{m_{\infty}^{\infty}}$ & \begin{tabular}{|c|c|}
1 \\
$\infty$ \\
$\infty$ \\
$\infty$ \\
1 \\
$i$ \\
\end{tabular} & की \\
\hline (TIL) 8u!̣.rodəy 1[nsəy & $\frac{0}{\underset{f}{f}}$ & \begin{tabular}{l}
$n$ \\
\multirow{0}{0}{} \\
$=$
\end{tabular} & $\begin{array}{l}n \\
\stackrel{2}{\Omega} \\
-\end{array}$ & के & 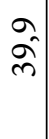 & $\begin{array}{l}n \\
0 \\
0 \\
-1\end{array}$ & $\stackrel{\substack{f \\
F}}{F}$ & $\hat{\sigma}$ & $\stackrel{0}{2}$ & $\begin{array}{l}m \\
\hat{\infty} \\
\hat{f}\end{array}$ & $\mid \begin{array}{l}10 \\
\infty \\
\infty \\
10 \\
i \\
ن\end{array}$ & $\begin{array}{l}\stackrel{+}{0} \\
\hat{\sim} \\
\stackrel{+}{+}\end{array}$ \\
\hline (TL) 8u!!!xM 1,odəy & 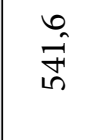 & $\begin{array}{l}\hat{\sigma} \\
\hat{2} \\
\hat{n}\end{array}$ & 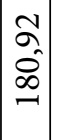 & \begin{tabular}{l}
$\infty$ \\
\multirow{2}{q}{}
\end{tabular} & $\hat{m}$ & $\begin{array}{l}\widehat{\sigma} \\
\stackrel{0}{ }\end{array}$ & $\stackrel{\substack{F \\
F}}{F}$ & $\stackrel{m}{0}$ & $\begin{array}{l}\infty \\
\hat{0}\end{array}$ & $\begin{array}{l}m \\
\hat{\infty}_{\phi} \\
\infty\end{array}$ & $\begin{array}{l}10 \\
\infty \\
\infty \\
10 \\
i\end{array}$ & $\begin{array}{c}n \\
\infty \\
\infty \\
\infty \\
\dot{+}\end{array}$ \\
\hline 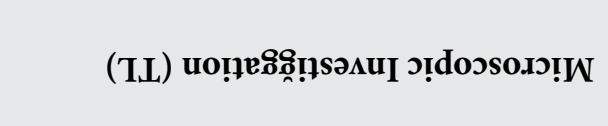 & $\begin{array}{l}n \\
\infty \\
\infty \\
m\end{array}$ & $\begin{array}{c}a \\
\hat{f} \\
\hat{\sigma}\end{array}$ & $\begin{array}{l}\hat{\jmath} \\
\hat{\curvearrowright}\end{array}$ & 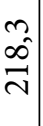 & $\stackrel{\stackrel{\leftrightarrow}{\sim}}{\mathrm{d}}$ & $\begin{array}{l}\stackrel{H}{\mathbb{N}} \\
\stackrel{\mathbb{N}}{N}\end{array}$ & $\hat{\imath}$ & $\begin{array}{l}n \\
\infty \\
\infty \\
\infty\end{array}$ & $\stackrel{m}{\stackrel{m}{f}}$ & $\overrightarrow{\widehat{o}}$ & $\begin{array}{l}\infty \\
\stackrel{\infty}{\Lambda} \\
\stackrel{0}{-i}\end{array}$ & $\begin{array}{l}0 \\
\hat{N} \\
\hat{~} \\
\text { in }\end{array}$ \\
\hline 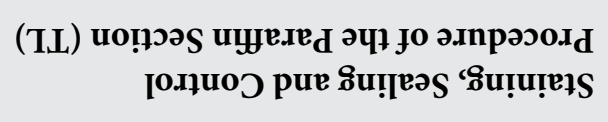 & $\stackrel{+}{\stackrel{n}{N}}$ & 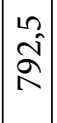 & 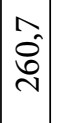 & $\stackrel{\infty}{\wedge}$ & $\stackrel{+}{\hat{N}}$ & 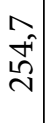 & 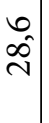 & $\begin{array}{c}\infty \\
\hat{\sigma} \\
-1\end{array}$ & กิ & $\stackrel{m}{\hat{m}}$ & 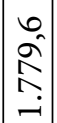 & 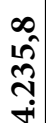 \\
\hline 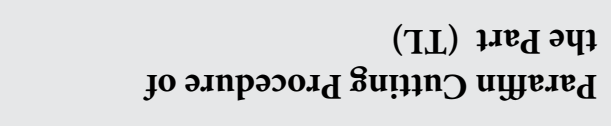 & $\stackrel{\infty}{\stackrel{\infty}{N}}$ & $\mid$\begin{tabular}{c}
$\infty$ \\
\multirow{4}{n}{} \\
in
\end{tabular} & 离 & 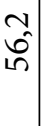 & $\hat{\sigma}^{2}$ & $\begin{array}{l}H \\
\partial\end{array}$ & $\begin{array}{l}\infty \\
\hat{i}\end{array}$ & $\begin{array}{l}0 \\
\stackrel{0}{a}\end{array}$ & $\stackrel{H}{\rightrightarrows}$ & 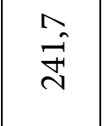 & 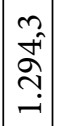 & $\mid \begin{array}{c}0 \\
\hat{o} \\
\dot{q} \\
\dot{m}\end{array}$ \\
\hline 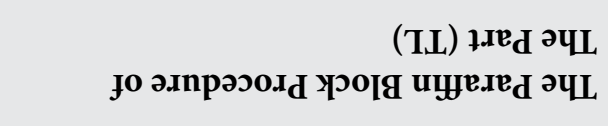 & $\stackrel{\infty}{\stackrel{\infty}{N}}$ & $\begin{array}{l}\hat{2} \\
\hat{n} \\
\tilde{n}\end{array}$ & 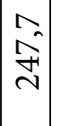 & \begin{tabular}{l}
\multirow{1}{n}{} \\
$\hat{0}$ \\
0
\end{tabular} & $\hat{\sigma}$ & 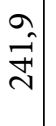 & $\begin{array}{c}\infty \\
\hat{i}\end{array}$ & $\stackrel{+}{\Delta}$ & $\stackrel{\mathscr{H}}{\stackrel{\mathscr{n}}{ \pm}}$ & 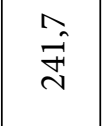 & 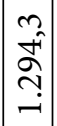 & 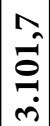 \\
\hline 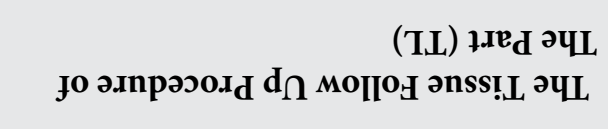 & ' & $\mid \begin{array}{l}a \\
10 \\
0 \\
n\end{array}$ & 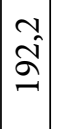 & $\hat{\hat{N}}$ & I & $\begin{array}{l}\infty \\
\infty \\
\infty \\
\infty \\
-1\end{array}$ & ' & $\begin{array}{l}n \\
\hat{n} \\
\tilde{n}\end{array}$ & $\stackrel{\sim}{\exists}$ & ' & ' & ָh \\
\hline 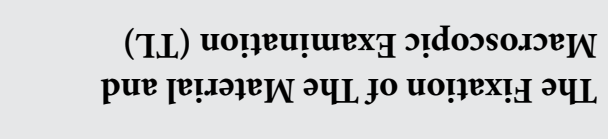 & 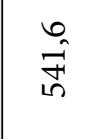 & $\mid \begin{array}{l}\infty \\
\stackrel{+}{+1} \\
\text { in }\end{array}$ & $\hat{\imath}$ & $\stackrel{\sim}{\infty}$ & $\hat{\tilde{n}}$ & $\begin{array}{c}c \\
\infty \\
\infty \\
\sim \\
\sim\end{array}$ & 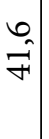 & $\vec{\approx}$ & $\stackrel{m}{\stackrel{N}{s}}$ & 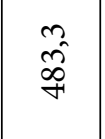 & $\left|\begin{array}{c}\stackrel{\rho}{+} \\
\infty \\
\infty \\
10 \\
i\end{array}\right|$ & 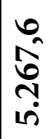 \\
\hline 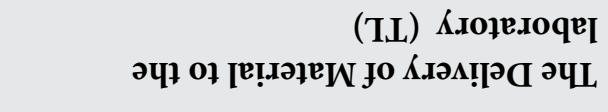 & $\stackrel{0}{0}$ & 1 & 1 & ' & $\stackrel{10}{N}$ & ' & $\stackrel{\infty}{\wedge}$ & & & $\stackrel{0}{8}$ & $\mid \begin{array}{c}m \\
2 \\
20 \\
\infty \\
+ \\
+1\end{array}$ & $\begin{array}{l}\infty \\
\hat{\sigma} \\
\hat{\sigma}\end{array}$ \\
\hline 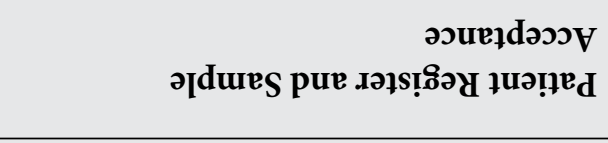 & 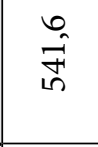 & $\begin{array}{l}0 \\
\stackrel{0}{\sim}\end{array}$ & 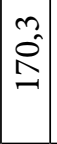 & के & $\hat{\sigma}$ & $\begin{array}{c}m \\
\operatorname{co}_{0}\end{array}$ & $\stackrel{\substack{f \\
F}}{F}$ & $\stackrel{\Rightarrow}{-1}$ & مे & $\overbrace{\substack{\infty \\
\infty}}^{m}$ & $\begin{array}{l}10 \\
\infty \\
\infty \\
10 \\
i \\
i\end{array}$ & 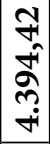 \\
\hline 官 & 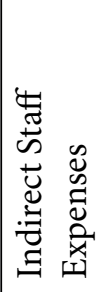 & 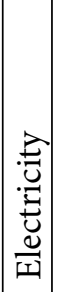 & 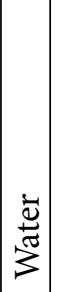 & 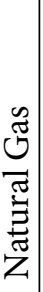 & 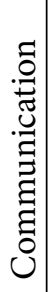 & 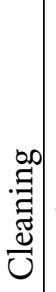 & 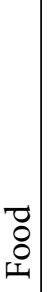 & 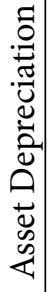 & 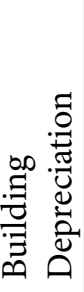 & 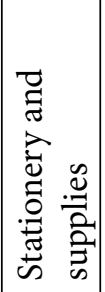 & $\mid \begin{array}{l}\bar{\Xi} \\
\tilde{\Xi} \\
0\end{array}$ & $\underset{0}{0}$ \\
\hline
\end{tabular}


Table IV: The total overall costs of the materials

\begin{tabular}{|c|c|c|c|c|c|c|c|c|c|c|c|c|}
\hline Material Type & 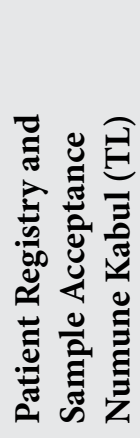 & 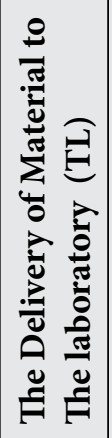 & 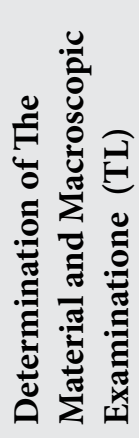 & 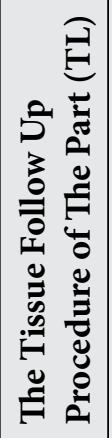 & 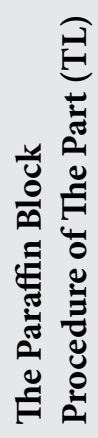 & 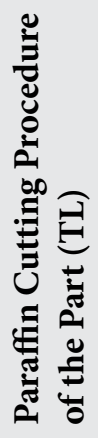 & 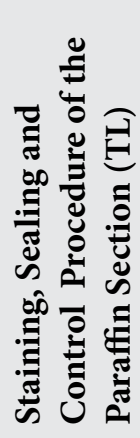 & 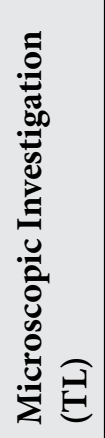 & 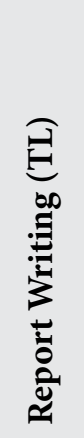 & 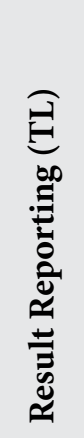 & 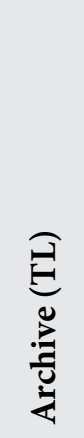 & 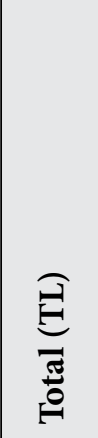 \\
\hline $\begin{array}{l}\text { Lung trans-bronchial } \\
\text { biopsy }\end{array}$ & 2,10 & 0,31 & 0,61 & 0,14 & 0,39 & 0,44 & 0,81 & 1,55 & 1,73 & 2,05 & 0,76 & 10,89 \\
\hline Kidney, biopsy needle & 2,10 & 0,31 & 0,61 & 0,14 & 0,39 & 1,28 & 8,83 & 10,98 & 9,58 & 2,05 & 2,33 & 38,60 \\
\hline $\begin{array}{l}\text { Prostate, needle biopsy } \\
\text { (quadrants } 10 \text { and over) }\end{array}$ & 2,10 & 0,31 & 7,30 & 1,96 & 8,19 & 6,21 & 0,88 & 6,66 & 5,15 & 2,05 & 9,76 & 50,57 \\
\hline $\begin{array}{l}\text { Lung, total/lobe/segment } \\
\text { resection }\end{array}$ & 2,10 & 0 & 9,29 & 1,96 & 4,37 & 4,03 & 1,39 & 6,90 & 7,45 & 2,05 & 5,67 & 45,57 \\
\hline
\end{tabular}

Table V: Unit costs of materials

\begin{tabular}{|l|c|c|c|c|}
\hline Material Type & $\begin{array}{c}\text { Direct Labor Cost } \\
\text { (TL) }\end{array}$ & $\begin{array}{c}\text { Direct Raw Material and } \\
\text { Supplies Cost (TL) }\end{array}$ & $\begin{array}{c}\text { Indirect Cost } \\
\text { (TL) }\end{array}$ & $\begin{array}{c}\text { Total Cost } \\
\text { (TL) }\end{array}$ \\
\hline $\begin{array}{l}\text { Lung trans-bronchial } \\
\text { biopsy }\end{array}$ & 8,54 & 3,55 & 10,89 & $\mathbf{2 2 , 9 8}$ \\
\hline Endometrium, curettage/biopsy & 13,90 & 3,55 & 13,16 & $\mathbf{3 0 , 6 1}$ \\
\hline Bone marrow biopsy & 37,22 & 5,47 & 14,41 & $\mathbf{5 7 , 1}$ \\
\hline Imprint Examination & 19,17 & 0,96 & 10,64 & $\mathbf{3 0 , 7 7}$ \\
\hline $\begin{array}{l}\text { Bone marrow thin needle } \\
\text { aspiration preparation evaluation }\end{array}$ & 19,79 & 0,96 & 11,62 & $\mathbf{3 2 , 3 7}$ \\
\hline Colon, biopsy & 6,06 & 3,55 & 9,34 & $\mathbf{1 8 , 9 5}$ \\
\hline Stomach, biopsy & 43,71 & 4,08 & 13,12 & $\mathbf{6 0 , 9 1}$ \\
\hline Bladder, biopsy & 8,23 & 3,55 & 10,35 & $\mathbf{2 2 , 1 3}$ \\
\hline Nasopharynx / oropharynx, biopsy & 7,18 & 3,55 & 10,80 & $\mathbf{2 1 , 5 3}$ \\
\hline $\begin{array}{l}\text { Fingers, hand/foot, amputation, } \\
\text { traumatic, ischemic }\end{array}$ & 24,92 & 34,47 & 26,06 & $\mathbf{8 5 , 4 5}$ \\
\hline Polyp, colorectal & 19,20 & 3,18 & 16,80 & $\mathbf{3 9 , 1 8}$ \\
\hline $\begin{array}{l}\text { Prostate needle biopsy (1-4 } \\
\text { quadrants) }\end{array}$ & 34,10 & 16,18 & 29,87 & $\mathbf{8 0 , 1 5}$ \\
\hline Gallbladder & 4,57 & 3,18 & 8,23 & $\mathbf{1 5 , 9 8}$ \\
\hline Tonsil or adenoids & 9,27 & 6,35 & 11,81 & $\mathbf{2 7 , 4 3}$ \\
\hline Lymph Nodes & 23,73 & 6,35 & 21,74 & $\mathbf{5 1 , 8 2}$ \\
\hline $\begin{array}{l}\text { Skin punch, incisional, shave } \\
\text { biopsy }\end{array}$ & 7,43 & 3,55 & 10,22 & $\mathbf{2 1 , 2}$ \\
\hline Appendix, except incidental & 4,60 & 3,18 & 8,17 & $\mathbf{1 5 , 9 5}$ \\
\hline Kidney, biopsy needle & 119,48 & 11,58 & 38,60 & $\mathbf{1 6 9 , 6 6}$ \\
\hline
\end{tabular}


Table V: Continuation

\begin{tabular}{|c|c|c|c|c|}
\hline Extremity, amputation, traumatic & 78,25 & 99,76 & 80,58 & 258,59 \\
\hline Liver, biopsy needle (wedge) & 54,35 & 9,60 & 25,60 & 89,55 \\
\hline Breast, biopsy & 13,43 & 3,21 & 13,27 & 29,91 \\
\hline Breast/reduction mammoplasty & 9,06 & 9,74 & 12,94 & 31,74 \\
\hline Peritoneum, biopsy & 11,65 & 3,55 & 12,64 & 27,84 \\
\hline $\begin{array}{l}\text { Prostate needle biopsy (5-9 } \\
\text { quadrants) }\end{array}$ & 40,09 & 36,41 & 42,46 & 118,96 \\
\hline Salivary gland, biopsy & 8,66 & 3,93 & 11,33 & 23,92 \\
\hline Brain/meninges, tumor resection & 15,10 & 12,76 & 17,06 & 44,92 \\
\hline Kidney partial/total nephrectomy & 40,09 & 38,19 & 39,63 & 117,91 \\
\hline Spleen & 28,08 & 22,42 & 27,12 & 77,62 \\
\hline Larynx partial/total resection & 72,63 & 65,38 & 64,26 & 202,27 \\
\hline $\begin{array}{l}\text { Breast, mastectomy - partial/ } \\
\text { simple }\end{array}$ & 61,01 & 102,93 & 72,93 & 236,87 \\
\hline Bladder, TUR & 13,54 & 12,73 & 16,11 & 42,38 \\
\hline $\begin{array}{l}\text { Prostate, needle biopsy (quadrants } \\
10 \text { and over) }\end{array}$ & 47,18 & 56,65 & 50,57 & 154,4 \\
\hline Thyroid, total/lobectomy & 28,08 & 50,80 & 35,17 & 63,25 \\
\hline Salivary gland (including tumor) & 28,63 & 47,60 & 34,70 & 110,93 \\
\hline Lung, total/lobe/segment resection & 51,52 & 48,12 & 45,57 & 145,21 \\
\hline $\begin{array}{l}\text { Tongue/tonsil - resection including } \\
\text { tumor }\end{array}$ & 46,75 & 33,65 & 44,02 & 124,42 \\
\hline Colon, total resection & 104,50 & 108,56 & 92,04 & 305,1 \\
\hline $\begin{array}{l}\text { Larynx, partial/total + neck lymph } \\
\text { nodules }\end{array}$ & 123,22 & 162,43 & 121,11 & 406,76 \\
\hline $\begin{array}{l}\text { Breast, mastectomy + axillary } \\
\text { lymph nodules }\end{array}$ & 74,71 & 133,42 & 86,47 & 294,6 \\
\hline Pancreas, total/subtotal resection & 68,01 & 92,01 & 72,39 & 232,41 \\
\hline Prostate, radical resection & 115,83 & 171,26 & 114,10 & 401,19 \\
\hline $\begin{array}{l}\text { Uterus, neoplastic (+/- fallopian } \\
\text { tubes and ovaries) }\end{array}$ & 55,76 & 73,14 & 57,98 & 186,88 \\
\hline Autopsy, fetus & 89,15 & 89,07 & 82,35 & 260,57 \\
\hline
\end{tabular}

costs. Within the investigations on the same level, those with very different unit cost and labor were found. When the material level categories on HIN list advanced from 1 to 4 , the procedure costs were found to be much more than the HSI fees. When the prices determined by the Medicare payment system for the same investigations were compared, the prices are higher than HIN because they are in United States standards. However, the price varieties were able to be classified in four different groups like in HIN. Especially in procedures requiring a high amount of labor, Medicare levels were found to be more realistic and consistent with the costs than HIN levels (Table VI).

\section{DISCUSSION}

Pathology investigations are different from all other laboratory investigations because the process steps have a large variety. In pathology investigations, macroscopic examination and sampling of the material, then the microscopic examination of the routine or special staining of the preparations prepared from it and the preparation of pathology report are steps completely performed by expert pathologists. The responsibility and the workload of the pathology specialist in concluding the pathology investigations are the reasons that prove the necessity of the compensation of the physician's work and pathology being a clinical speciality. 
Table VI: Unit costs of pathological investigations classified according to HCN levels and HCN and Medicare prices

\begin{tabular}{|c|c|c|c|c|c|}
\hline Material Type & $\begin{array}{l}\text { Unit Cost } \\
\text { (TL) }\end{array}$ & $\begin{array}{l}\text { Unit Cost } \\
\qquad(€) \mathrm{e}\end{array}$ & $\begin{array}{l}\text { Unit Cost } \\
\text { (\$) e }\end{array}$ & $\begin{array}{c}\text { HCN Price } \\
\text { (TL) } \\
* * * *\end{array}$ & $\begin{array}{l}\text { Medicare } \\
\text { Price } \\
(\$)(14)\end{array}$ \\
\hline \multicolumn{6}{|l|}{ First Level } \\
\hline Lung trans-bronchial biopsy & 22,98 & 11,58 & 15,89 & 31,79 & 106,79 \\
\hline Endometrium, curettage/biopsy & 30,61 & 15,42 & 21,17 & 31,79 & 106,79 \\
\hline Bone marrow biopsy & 57,10 & 28,77 & 39,49 & 31,79 & $256,64^{*}$ \\
\hline Imprint examination & 30,77 & 15,50 & 21,28 & 11,22 & 84,64 \\
\hline $\begin{array}{l}\text { Bone marrow thin needle aspiration preparation } \\
\text { evaluation }\end{array}$ & 32,37 & 16,31 & 22,39 & 32,67 & 84,64 \\
\hline Colon, biopsy & 18,95 & 9,55 & 13,11 & 31,79 & 68,70 \\
\hline Stomach, biopsy $+1 \mathrm{x}$ special staining & 60,91 & 30,69 & 42,13 & 58,85 & 68,70 \\
\hline Bladder, biopsy & 22,13 & 11,15 & 15,31 & 31,79 & 106,79 \\
\hline Nasopharynx / oropharynx, biopsy & 21,53 & 10,85 & 14,89 & 31,79 & 106,79 \\
\hline Fingers, hand/foot, amputation, traumatic, ischemic & 85,45 & 43,06 & 59,10 & 31,79 & $132,88^{*}$ \\
\hline Polyp, colorectal & 39,18 & 19,74 & 27,10 & 31,79 & 106,79 \\
\hline Prostate needle biopsy (1-4 quadrants) & 80,15 & 40,39 & 55,43 & 31,79 & $\begin{array}{c}106,79 \\
-427,16 \\
(4 X 106,79)\end{array}$ \\
\hline Gallbladder & 15,98 & 8,05 & 11,05 & 31,79 & 61,53 \\
\hline Tonsil or adenoids & 27,43 & 13,82 & 18,97 & 31,79 & 61,53 \\
\hline Skin punch, incisional, shave biopsy & 21,20 & 10,68 & 14,66 & 31,79 & 106,79 \\
\hline \multicolumn{6}{|l|}{ Second Level } \\
\hline Lymph nodes & 51,82 & 26,11 & 35,84 & 41,03 & 106,79 \\
\hline Appendix, except incidental & 15,95 & 8,04 & 11,03 & 41,03 & 61,53 \\
\hline Stomach, biopsy $+4 \mathrm{x}$ special staining & 169,66 & 85,49 & 117,34 & 149,27 & $367,99^{* *}$ \\
\hline Extremity, amputation, traumatic & 258,59 & 130,30 & 178,84 & 41,03 & 106,79 \\
\hline $\begin{array}{l}\text { Liver, biopsy needle wedge (wedge) } \\
\text { 2x special staining }\end{array}$ & 89,55 & 45,12 & 61,93 & 95,15 & 366,81 \\
\hline Breast, biopsy & 29,91 & 15,07 & 20,69 & 41,03 & 106,79 \\
\hline Breast/reduction mammoplasty & 31,74 & 15,99 & 21,95 & 41,03 & 106,79 \\
\hline Peritoneum, biopsy & 27,84 & 14,03 & 19,25 & 41,03 & 106,79 \\
\hline Prostate needle biopsy (5-9 quadrants) & 118,96 & 59,94 & 82,27 & 41,03 & $\begin{array}{c}533,95- \\
961,11 \\
(5 / 9 X 106,79) \\
\star \star \star \star\end{array}$ \\
\hline Salivary gland, biopsy & 23,92 & 12,05 & 16,54 & 41,03 & 106,79 \\
\hline \multicolumn{6}{|l|}{ Third Level } \\
\hline Brain/meninges, tumor resection & 44,92 & 22,63 & 31,07 & 43,89 & 236,21 \\
\hline Kidney partial/total nephrectomy & 117,91 & 59,41 & 81,55 & 43,89 & 236,21 \\
\hline Spleen & 77,62 & 39,11 & 53,68 & 43,89 & 106,79 \\
\hline Larynx partial/total resection & 202,27 & 101,92 & 139,89 & 43,89 & 236,21 \\
\hline Breast, mastectomy - partial/simple & 236,87 & 119,35 & 163,82 & 43,89 & 236,21 \\
\hline
\end{tabular}


Table VI: Continuation

\begin{tabular}{|c|c|c|c|c|c|}
\hline Bladder, TUR & 42,38 & 21,35 & 29,31 & 43,89 & 236.21 \\
\hline Prostate, needle biopsy (quadrants 10 and over) & 154,40 & 77,80 & 106,78 & 43,89 & $\begin{array}{c}1.067,9- \\
1.281,48 \\
(10 / 12 \\
\mathrm{X} 106,79)^{\star * *}\end{array}$ \\
\hline Thyroid, total/lobectomy & 63,25 & 31,87 & 43,74 & 43,89 & 236,21 \\
\hline Salivary gland (including tumor) & 110,93 & 55,90 & 76,72 & 43,89 & 236,21 \\
\hline \multicolumn{6}{|l|}{ Fourth Level } \\
\hline $\begin{array}{l}\text { Lung, total/lobe/segment resection }+1 \mathrm{x} \text { special } \\
\text { staining }\end{array}$ & 145,21 & 73,17 & 100,43 & 93,06 & 358,57 \\
\hline Tongue/tonsil - resection including tumor & 124,42 & 62,69 & 86,05 & 66,00 & 358,57 \\
\hline Colon, total resection & 305,10 & 153,73 & 211,01 & 66,00 & 358,57 \\
\hline Larynx, partial/total + neck lymph nodules & 406,76 & 204,96 & 281,32 & 66,00 & 358,57 \\
\hline Breast, mastectomy + axillary lymph nodules & 294,60 & 148,44 & 203,75 & 66,00 & 358,57 \\
\hline Pancreas, total/subtotal resection & 232,41 & 117,11 & 160,74 & 66,00 & 358,57 \\
\hline Prostate, radical resection & 401,19 & 202,15 & 277,47 & 66,00 & 358,57 \\
\hline Uterus, neoplastic (+/- fallopian tubes and ovaries) & 186,88 & 94,17 & 129,25 & 66,00 & 358,57 \\
\hline \multicolumn{6}{|l|}{ Autopsies } \\
\hline Autopsy, fetus & 260,57 & 131,30 & 180,21 & 55,99 & 358,57 \\
\hline \multicolumn{6}{|l|}{ Special Investigations } \\
\hline Frozen examination (İbni Sina) & 523,05 & 263,55 & 361,75 & 42,02 & $\begin{array}{c}149,221 \\
+ \\
\mathrm{X} 42,02\end{array}$ \\
\hline Frozen examination (Cebeci) & $2.585,76$ & $1.302,91$ & $1.788,34$ & 42,02 & $\begin{array}{c}149,221 \\
+ \\
\mathrm{X} 42,02\end{array}$ \\
\hline
\end{tabular}

$* \$ 19,25$ decalcification price is included.

${ }^{*} \$ 65,30$ special histochemical staining is included in the price, whatever quantity is required.

$\star * *$ In multiple prostate needle biopsies, the total price is determined by multiplying the number of samples up to 12 quadrants and the unit price of $\$ 106,79$ in the Medicare system. For this reason, the prices in this section are given as example of the lowest and highest limit of HCN levels. However, the multiplier disappears over 12 quadrants and a $\$ 382,01$ fixed price is paid.

**** The HCN prices for the University Hospitals are prices determined for 2010 October taken as the model in this study. Today, the prices are approximately $10 \%$ lower. (21)

1: The frozen investigation was calculated by adding macroscopy and microscopy. When there is more than one frozen investigation taken from the same patient at the same operation, $\$ 42,02$ pricing will be applied for ach investigation.

e: Republic of Turkey Central Bank 1 October 2010 exchange rate is used (\$: 1,4459 TL, €: 1,9846 TL).

Pathology procedures may have a different labor amount and workload than the interventional procedure or surgery for obtaining the tissues. Bone marrow, kidney, and liver biopsies are the best examples. The workloads of pathologists for various pathology investigations in different countries have been presented by associating it with the procedure steps (17-19). This is the only way to understand the real value of the investigation. The most important scale evaluated here is the time spent to do the job. In the cost analysis we performed by using the $\mathrm{ABC}$ method, the ratio of the work of the physicians is higher than the other steps within the direct laboring and general production costs, as seen in Table II, IV.

Within pathology investigations, small biopsies evaluated by routine staining in a single paraffin block are at one end in terms of cost while big resection materials requiring a lot of sampling for determination of tumor stage are at the other end. When the block and section number is increased to investigate the pathology material sufficiently, the raw material and supplies costs rise (Table I). Multiple prostate 
needle biopsies is the best example for this. In our country, the multiple biopsy samples taken at the same session from the same organ have always been subjected to a single price in the past but then each biopsy fee payment began to be accepted on the basis of each anatomical region, for example for mucosa biopsies such as from the stomach and colon. In prostate multiple biopsies, a single biopsy payment was made for up to 12 quadrants in the past. These investigations were later staged in the HIN, and put in different levels according to the number of biopsies $(20,21)$. However, our study has clearly shown that these changes definitely do not cover the costs of these investigations (Table V, VI). The same investigations are priced by the multiplication of number of biopsies and unit price in the Medicare system (14). The workload must be taken into account in the evaluation of investigations like these (1719).

In the $\mathrm{ABC}$ analysis system, the general costs of the hospital or buildings of the laboratories must be reflected in the cost to calculate the real cost. The cost reflected here may show a big difference between institutions. The percentage of the share of overall production costs in the total cost increases depending on the feature and evaluation time of the material and its degree of difficulty (Table III, Table IV). Indirect cost is a parameter related to the total material number the laboratories annually investigate. In pathology laboratories of hospitals which have few patients and investigate little material, the indirect costs will be high, and the investigation cost will increase by their reflection on the total cost. The best example in our study is the huge cost gap between frozen investigations performed in the frozen units of İbn-i Sina Hospital and Cebeci Hospital (Table VI).

Due to the presence of very different investigations in terms of both supplies and labor costs in the four level determined in the HIN list regarding pathology investigations, we evaluated investigations with such differences in our study. We made sure that the equivalents that have similar costs for investigations that are not in this list were present in our model list. We found significant differences between the unit costs of the materials investigated in the study and prices on the HIN list. If evaluated according to the levels, $69,22 \%$ of the materials on the 1 st level showed a cost under HIN prices and $30,78 \%$ showed a cost over HIN prices. A cost under HIN prices was found in $62,50 \%$ of second level histopathological investigations, and a cost over HIN prices in $37.50 \%$. For the third level histopathological investigations, a cost over HIN prices was found in $88,88 \%$ and a cost under HIN prices in $11,12 \%$. On the fourth level, the costs of all investigations studies were found to be approximately 2 to 6 times higher than HIN prices. Fourthlevel HIN prices did not even cover the costs of the direct raw materials and supplies used in investigations. When the cost of materials with special staining were compared with HIN prices, $40 \%$ of them were found to be higher than HIN prices and $60 \%$ of them lower than HIN prices. For frozen investigation, the unit costs were found to be high as the number of material received is low but laboratory expenses are high. The aim of our study was to calculate the unit costs of the pathology investigations, so the evaluations regarding the prices of these investigations were made separately using HIN Attachment 8. A package fee including other investigations related to pathology and surgery are applied by the SSI for some surgeries or interventional procedures. Since the cost analysis studies including all elements within the scope of the package should be done separately, an evaluation regarding the package prices has not been performed in the cost account in our study.

When the United States of America (USA) Medicare 2012 payment system is examined, the prices determined for the investigations there are higher than in our country and our costs because the labor expenses and the supply cost that the laboratory standards require in that country are high. Pathology procedures are labor-intensive investigations, and the costs and prices are therefore directly influenced by the wages of the physicians and other healthcare staff. The low wage policy applied towards the healthcare employees in Turkey paves the way to service costs being calculated lower than the examples abroad. This situation is clearly seen when the costs calculated with our study are compared with the Medicare prices. The factors that create the price and the health systems are different from each other, making the statistical discussion of the consistency of prices of similar investigations on HIN and Medicare lists impossible. We therefore made the comparisons not with the Medicare system prices but with price levels that have similar fees. It is interesting that there are very different investigations in terms of cost although they are on the same level as determined for the pathology investigations on the HIN list applied in Turkey. Here, these prices are understood to be determined by associating the investigations with their real costs, without evaluation of work load, and classified incorrectly. In the first level, bone marrow biopsy and imprint investigation, and benign amputations are investigations with prices well below their costs. In the Medicare system, bone marrow biopsy is charged at the third level. Imprint and aspirations have fees between the first and second levels. Benign amputations are at the second level. Kidney and liver biopsies which 
are at the 2nd level on the HIN list and require much more work and special staining are seen to be charged at the fourth level in Medicare (14) (Table VI). We clearly demonstrated in our study that the charge applied for the 3rd and 4th level pathology investigations on the HIN list associated are not associated with their cost equivalents at all. The investigations within this scope generally include small or big resections performed due to tumor. These investigations should be done correctly for diagnosis and correct staging. Otherwise, it will lead to incomplete or unnecessarily excessive postoperative treatment of cancer patients with the inevitable result that the general costs of the patient treatment will increase.

There is no other study performed in the pathology laboratory using the $\mathrm{ABC}$ system, and we are therefore unable to compare our data in this respect. However there are studies performed by using the $\mathrm{ABC}$ system in various disciplines of the health sector in the literature. Similar conclusions were also reached in these studies. For example, in the study of Bakhshayesh performed in 1999, unit prices of some tests studied in the biochemistry and bacteriology laboratory were calculated (15). The study found unit costs of 38,101 TL unit price for the hemoglobin test, 38,33 TL for the cholesterol test and 186,479 TL for other tests while the unit price was found to be 123,41 TL when the costs of the same tests were calculated by using the traditional methods. A similar study was conducted by Ağyar in 2006 in the Urology department (4). The study found the sale price of Radical Nephrectomy surgery to be $732,72 \mathrm{TL}$, while the actual cost was $817,77 \mathrm{TL}$, and the sale price of Nephrolithotomy surgery was 821,97 TL while the actual cost was $1.175,44$ TL. Besides, some surgery costs were determined to be below the sale prices. For example, hypospadias proximal surgery sale price was $622,51 \mathrm{TL}$, while the actual cost was found to be 340,91 TL. In a study conducted in the gynecology service, birth with C-section and normal birth costs were calculated by using traditional and $\mathrm{ABC}$ systems (16). As a result, cost of birth with C-section was 722.321,674 TL according to the traditional system, and $642.768,600 \mathrm{TL}$ according to the $\mathrm{ABC}$ system. The sale price of birth with C-section was 1.050 TL. For normal birth, the cost was 316,940 $\mathrm{TL}$ according to the traditional system, and 371,305 TL according to the $\mathrm{ABC}$ system. The sale price of normal birth was 590 TL. In the study performed by Erkol and Ağırbaş in 2010 at the Cardiovascular Surgery department, some surgeries performed at this department were examined (1). The results found were compared with HIN and the invoice amounts of the hospital. As a result of the study, the biggest difference was found to be in Fallot Tetralogy surgery. The HIN price was $7.262,50 \mathrm{TL}$, the invoice amount 14,371 TL and the actual cost determined by the study 20,035 TL. As seen in these studies, the costs of the services submitted in the health sector differ according to the cost calculation systems used and prices determined by the institutions but the $\mathrm{ABC}$ system gives more detailed, accurate results than the traditional system.

As seen from the results obtained in this study, there are significant differences between the pathology prices and real costs of these investigations. This indicates that the determination of prices without cost analysis can lead to higher or lower pricing than the actual cost. Hospitals claim that the prices the reimbursement institutions determine unilaterally are very low leading to providing a service below its cost and without profit. However, hospitals do not have the evidence to document these claims and these statements therefore do not adequately influence the decisions of the reimbursement institutions. The cost results determined by our study may play a guiding role in determining HIN prices. Professional organizations like the SSI and Turkish Physicians Association have developed pricing rules without using the data of comprehensive cost studies which show the real cost as in our study. However, other expenses of the hospitals reflected in the cost should also be added to these calculations. The method used in this study presents the data from which we can determine all expense types and stages reflecting on the cost, and it can help different institutions calculate their own costs and can be used as a guide enabling the hospital administration to take precautions to decrease these costs. We therefore believe the study will contribute positively to this process and can provide guidance for the presentation of cost differences between the institutions by performing similar studies in different hospitals. Besides, the ABC system is a method that enables the diagnosis and treatment processes to be examined by both employees and managers from a different point of view. The application of this system should be recommended in all hospitals to increase the awareness of the healthcare staff regarding the organizational structure and mechanisms of the hospital, The results obtained by using the $\mathrm{ABC}$ system in our study are thought to be a tool for laboratory managers to be used in financial planning, productivity control, determining contribution to quality and realistic resource usage, and cost control. This study is the most comprehensive study in Turkey towards the determination of pathology procedure costs. We think that SSI and health institutions should benefit from the study results and performing similar studies in other hospitals 
should contribute to the diagnostic pathological tests in our country being presented with their real value to achieve the quality they deserve.

\section{ACKNOWLEDGMENTS}

We would like to thank Ankara University Medical Faculty Department of Pathology Faculty members Dr. Serpil Sak, Dr. Esra Erden, Dr. Aylin O Heper, Dr. Gülşah Kaygusuz; Dr. Ayça Karabörk, Dr. Saba Kiremitçi; Residents Dr. Seher Yüksel, Dr. Banu Alkan, Dr. Elçin Kadan, Dr. Ayşegül Şahin; Laboratory technicians, Melek Kuyucu, Şakir Pınar, Kadriye Yücel, İlknur Türkmen, Mesut Özkale, Kader İnce, Zeki Karabulut; Registry officers Şenol Karabiber, Mehmet Durmuş; Report secretaries Ayten Saydam, Münire Güçlü, Hayriye Sürücü, Selda Demiroğlu; Archive officer Yusuf Arslan; Quality coordinator Şebnem Yonar for their contribution at the data collection stage of the study. We thank Dr. Serhan Alkan for his contribution regarding the Medicare system applications.

\section{REFERENCES}

1. Erkol Ü, Ă̈ırbaş İ: Hastanelerde faaliyet tabanlı maliyetleme yöntemine dayalı bir uygulama. Ankara Üniversitesi Tıp Fakültesi Mecmuası 2011, 64:87-95

2. Fidan D: Ekonomik değerlendirme yöntemleri. Sağlık Ekonomisi Dergisi 2009, 1:4-7

3. Esatoğlu AE, Ağırbaş I, Payzıner DP, Akbulut Y, Göktaş B, Özatkan Y, Uğurluoğlu E, Yildırım T, Törüner M, Gök H, Atasoy Ç, Çakır S, Ökten İ: Ankara Üniversitesi Tip Fakültesi Hastaneleri'nde maliyet analizi. Ankara Üniversitesi Tip Fakültesi Mecmuası 2010, 63:17-27

4. A $\breve{g}$ yar $\boldsymbol{E}$ : Hastane işletmelerinin yönetimi açısından çağdaş maliyetleme yöntemlerinden faaliyet tabanlı maliyetleme ve kalite maliyetlemenin değerlendirilmesi: Bir Uygulama. Doktora Tezi. Akdeniz Üniversitesi Sosyal Bilimler Enstitüsü Antalya, 2006

5. Okudan K: Faaliyet tabanlı maliyetlendirme analizinin işletme yönetimindeki karar alma sürecine etkisi ve buna yönelik bir uygulaması. Yüksek Lisans Tezi. Yıldız Teknik Üniversitesi, Fen Bilimleri Enstitüsü, İstanbul, 2005

6. Esmeray A: Hastanelerde maliyetleme ve faaliyete dayalı maliyetlemeye ilişkin bir uygulama. Doktora Tezi. Erciyes Üniversitesi, Sosyal Bilimler Enstitüsü, Kayseri, 2006

7. Özcan F: Faaliyet tabanlı maliyetleme ve tıbbi laboratuvar uygulaması. Yüksek Lisans Tezi. Kocaeli Üniversitesi, Sosyal Bilimler Enstitüsü, Kocaeli, 2006
8. Seçkin A: Faaliyet tabanlı maliyetleme ve bir hastane işletmesi üzerinde uygulama. Yüksek Lisans Tezi. Niğde Üniversitesi Sosyal Bilimler Enstitüsü, Niğde, 2008

9. Özyapıcı $\mathrm{H}$ : An implementation of time driven activity based costing system in a healthcare institution. Yüksek Lisans Tezi. Marmara Üniversitesi Sosyal Bilimler Enstitüsü, İstanbul, 2008

10. Thomas JH: Activity based information: A blueprint for world class management accounting. Management accounting 1988, 69: 23-30

11. Judith BJ: Activity-based costing and activity-based management for health care United States of America: Aspen Publishers, Inc., 1998, 1-6

12. Haluk B, Seçkin A: Hastane işletmesinde faaliyet tabanlı maliyetleme uygulamasi. Afyon Kocatepe Üniversitesi, İktisadi ve İdari Bilimler Fakültesi Dergisi 2009, 9:55-78

13. Tunga AA: Faaliyet tabanlı maliyet sistemi ve bir uygulama. Selçuk Üniversitesi Sosyal Bilimler Enstitüsü Dergisi 2005, 13:39-56

14. Pathology Service Coding Handbook: Medical Service, Procedure and Diagnosis Reporting Policies and Practices for the Pathology Profession Version 12.1 (January 1, 2012) DLPadget Enterprises, Inc. Available from: http://www.wpsmedicare.com

15. Bakhshayesh A: Hastanelerde faaliyete dayalı maliyetleme. Bilim Uzmanlığı Tezi, Hacettepe Üniversitesi Sağlık Bilimleri Enstitüsü, Ankara, 1999

16. Öker F: Faaliyet tabanlı maliyetleme: Üretim ve Hizmet İşletmelerinde Uygulamalar. İstanbul, Literatür Yayınları, 2003, $141-165$

17. Maung R: Canadian Association of Pathologists guidelines for measurement of pathologist workload. Canadian J Pathol 2010, 2: 8-19

18. Thorpe A, Al-Jafari M, Allen D, Carr R, Helliwell T Sanders $S$ : Guidelines on staffing and workload for histopathology and cytopathology departments (3rd edition) 2012, The Royal College of Pathologists Registered Charity in England and Wales, no. 261035, Available from: http://www.rcpath.org/ Resources/RCPath/Migrated\%20Resources/Documents/G/ G107_GuidelinesStaffingWorkload_Apr12.pdf

19. Meijer GA, Oudejans JJ, Koevoets JJM, Meijer CJLM: Activitybased differentiation of pathologists' workload in surgical pathology. Virchows Arch 2009, 454:623-628

20. 2008 Yılı Sosyal Güvenlik Kurumu Sağlık Uygulama Tebliği Resmi gazete 29 Eylül 2008 PAZARTESİ Sayı: 27012 (Mükerrer) Ek 8. Available from: http://www.resmigazete.gov.tr/eskiler/ 2008/09/20080929M1-1.htm

21. Sosyal Güvenlik Kurumu Sağlık Uygulama Tebliği (SUT) Resmi gazete 25 Mart 2010 Perşembe Sayı: 27532 (Mükerrer) Ek 8. Available from: http://www.resmigazete.gov.tr/eskiler/2010/03/ 20100325M1-1.htm 